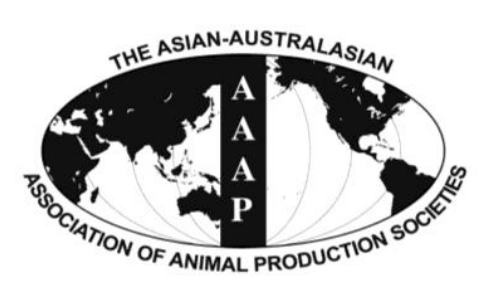

\title{
Effects of Housing Systems and the Diet Supplements on the Slaughter Value and Concentration of Mineral Elements in the Loin Muscle of Lambs
}

\author{
M. Gabryszuk*, E. Kuźnicka ${ }^{1}$, K. Horbańczuk, and J. Oprządek \\ Institute of Genetics and Animal Breeding, Polish Academy of Sciences, Jastrzębiec, 05-552 Magdalenka, Poland
}

\begin{abstract}
The objective of this study was to investigate the effect of maintenance system as well as the effect of Se, Zn, and vitamin E supplementation of ram-lambs on the slaughter value and concentration of mineral elements in the loin muscle of lambs. The experiment was conducted on 72 Polish Merino ram-lambs divided into three groups: group C, indoor with no supplement, 19 lambs; S, indoor with supplement, 23 lambs; G, outdoor with no supplement, 30 lambs. From birth all the lambs were maintained indoor with their dams and then weaned at the age of 8 weeks. The rams from group $\mathrm{C}$ and $\mathrm{S}$ were placed in individual straw-bedded pens and fattened individually with concentrate mixture offered ad libitum until the age of 16 weeks. The lambs from group $\mathrm{G}$ were grazed every day from May to July (2 months). During the fattening period each lamb from the supplemented group S was administered per os $1 \mathrm{~mL} 0.1 \%$ $\mathrm{Na}_{2} \mathrm{SeO}_{4}(\mathrm{Se}, 0.42 \mathrm{mg}), 3 \mathrm{~mL} 10 \% \mathrm{ZnSO}_{4}(\mathrm{Zn}, 68 \mathrm{mg})$, and $1 \mathrm{~mL}$ premix protect vitamin $\mathrm{E}(0.1 \mathrm{~g}$ - -tocopherol, $5 \mathrm{mg}$ lysine, $5 \mathrm{mg}$ methionine) daily. A comparison of half carcasses across the groups has shown no difference between the control group and the one with supplements, while the weight of half carcasses in the grazing group was smaller in comparison with groups $\mathrm{C}$ and $\mathrm{S}(\mathrm{p}<0.001)$. The meat content in the pelvic limb showed no differences across all groups under study. The pelvic limb of grazing lambs contained less fat compared to the control and supplemented groups $(\mathrm{p}<0.001)$. The concentrations of Se and $\mathrm{Zn}$ in the blood plasma of ram-lambs from the supplemented group were significantly higher than for the control and grazing lambs. Inorganic Se and $\mathrm{Zn}$ supplementation with vitamin $\mathrm{E}$ to the diet of lambs increased Se and $\mathrm{Zn}$ levels in loin muscle $(\mathrm{p}<0.001)$ to $0.46 \mu \mathrm{g} / \mathrm{g}$ and $32.9 \mu \mathrm{g} / \mathrm{g}$ in fresh tissue, respectively. (Key Words: Lambs, Selenium, Zinc, Housing System, Carcass, Meat Quality)
\end{abstract}

\section{INTRODUCTION}

Current trends show that the quality of animal products is of increasing importance to consumers and markets demanding lean meat. The lamb's growth rate and carcass quality depends on the environmental conditions during the fattening period. Ram lambs kept in warm barn pens spend less energy on body warming, thus storing it up as fat tissue. Cold environments increase the maintenance requirements and may reduce fat deposition in grazing lambs. Moreover, the energy expenditure for walking causes a lower fat tissue

\footnotetext{
* Corresponding Author: Mirosław Gabryszuk. Tel: +48-2273 67129, Fax: +48-227561417, E-mail: M.Gabryszuk@ighz.pl

${ }^{1}$ Faculty of Animal Science, Warsaw University of Life Sciences SGGW, 02-786 Warsaw, Poland.

Submitted Oct. 17, 2013; Revised Dec. 16, 2013; Accepted Dec. 30, 2013
}

deposition. The carcasses of the walking ram lambs contained less fat in comparison with carcasses of those confined in pens (Kuźnicka, 2006). Meat quality also depends on mineral elements such as $\mathrm{Se}$ and $\mathrm{Zn}$ as well as vitamin E content. Selenium, $\mathrm{Zn}$, and vitamin E administered orally to growing ram-lambs induced a decrease in cholesterol content in blood and meat, and led to increased CLA isomers level in meat and liver (Gabryszuk et al., 2007).

For large areas of the world, the consumption of the selenium by people is insufficient (Fairweather-Tait et al., 2011). Also, zinc deficiency is very widely prevalent throughout the world. It is more prevalent in developing countries, due the consumption of protein cereals (SchlegelZawadzka, 2011). In light of this, increased consumption of meat enriched with Se and Zn may provide a means for

Copyright $@ 2014$ by Asian-Australasian Journal of Animal Sciences This is an open-access article distributed under the terms of the Creative Commons Attribution Non-Commercial License (http://creativecommons.org/licenses/by-nc/3.0/), which permits unrestricted non-commercial use, distribution, and reproduction in any medium, provided the original work is properly cited. 
improving the Se and $\mathrm{Zn}$ status in humans.

The aim of this study was to elucidate the effect of housing systems as well as the effect of $\mathrm{Se}, \mathrm{Zn}$ and vitamin E supplementation of ram-lambs on the slaughter value and concentration of mineral elements in the loin muscle of lambs.

\section{MATERIALS AND METHODS}

\section{Animals and treatments}

This study was approved by the III Local Animal Ethics Committee in Warsaw Nr. 27/2009. The experiment was conducted on 72 single born Polish Merino ram-lambs divided into three groups: control, indoor with no supplement (C), 19 rams; indoor with supplement (S), 23 rams; outdoor with no supplement $(\mathrm{G}), 30$ rams. Until the age of 8 weeks all lambs were maintained indoor with their dams. Then the lambs were weaned, and all from groups $C$ and $S$ were placed in individual straw-bedded pens and fattened individually with a concentrate mixture (Table 1) offered ad libitum until the age of 16 weeks. The concentrate was composed of $40 \%$ oat meal, $29 \%$ wheat-rye meal, $19.5 \%$ soy-bean meal, $10 \%$ rapeseed cake, $1 \%$ limestone and $0.5 \% \mathrm{NaCl}$. In order to ensure proper rumen function, each lamb was additionally offered about $0.1 \mathrm{~kg}$ meadow hay daily. The lambs from group $\mathrm{G}$ were grazed every day from May to July ( 2 months) from 7 am to $6 \mathrm{pm}$. From $6 \mathrm{pm}$ to $7 \mathrm{am}$ the lambs kept also outdoor but in the lairage and under the roof. Each lamb from group $\mathrm{G}$ except green forage received about $0.1 \mathrm{~kg}$ meadow hay and $0.1 \mathrm{~kg}$ grain oat daily. The rams from groups $\mathrm{C}$ and $\mathrm{S}$ were highinput maintenance, but rams from group $G$ were low-input maintenance. During the fattening period (60 days) each lamb from supplemented group $\mathrm{S}$ was administered per os 1 $\mathrm{mL} 0.1 \% \mathrm{Na}_{2} \mathrm{SeO}_{4}(\mathrm{Se}, 0.42 \mathrm{mg}), 3 \mathrm{~mL} 10 \% \mathrm{ZnSO}_{4}(\mathrm{Zn}, 68$ $\mathrm{mg})$, and $1 \mathrm{~mL}$ premix protect Vitaminum E $(0.1 \mathrm{~g}$ $\alpha$-tocopherol, $5 \mathrm{mg}$ lysine, $5 \mathrm{mg}$ methionine) daily. The proximate analysis of feeds (Table 1) was performed using standard procedure. During fattening and grazing the animals were weighed at the beginning and at the end of fattening. At the beginning and the end of fattening blood

Table 1. Chemical composition of feeds (g/kg DM)

\begin{tabular}{lcccc}
\hline Item & Concentrate $^{1}$ & Meadow hay & Pasture & Oats \\
\hline Organic matter & 912 & 922 & 908 & 970 \\
Crude protein & 192 & 82 & 152 & 91 \\
Crude fibre & 106 & 303 & 249 & 126 \\
Ether extract & 36 & 20 & 30 & 34 \\
$\mathrm{NDF}$ & 282 & 566 & 471 & 356 \\
$\mathrm{ADF}$ & 124 & 361 & 321 & 164 \\
$\mathrm{Se}(\mathrm{mg} / \mathrm{kg} \mathrm{DM})$ & 0.16 & 0.09 & 0.09 & 0.1 \\
$\mathrm{Zn}(\mathrm{mg} / \mathrm{kg} \mathrm{DM})$ & 27.2 & 14.9 & 15.1 & 19.8 \\
\hline
\end{tabular}

${ }^{1}$ The concentrate was composed of $40 \%$ oat meal, $29 \%$ wheat-rye meal, $19.5 \%$ soy-bean meal, $10 \%$ rapeseed cake, $1 \%$ limestone and $0.5 \% \mathrm{NaCl}$ was withdrawn from the jugular vein of lambs for determination of trace elements in the plasma.

\section{Slaughter and carcass estimation}

At the end of fattening (week 16 of life) all lambs were slaughtered for carcass quality estimation using methodology recommended by the National Research Institute of Animal Production (Krupiński, 2009), which meets requirements of the European Union (Carrasco et al., 2009b). After slaughter, carcasses were chilled at $4^{\circ} \mathrm{C}$ for 24 h. Objective measurements of carcasses were recorded: hind leg deepness, pelvic limb length and hind leg circumference for calculation of the hind leg tightness index. The carcass was split longitudinally and the two halves were weighed. The kidney with pelvic fat from the left carcass side was removed and weighed to obtain the contents of the kidney knob and channel fat (KKCF). The left side was divided into shoulder, breast, pelvic limb (leg cut between the sixth and seventh lumbar vertebrae), neck (from the first to sixth cervical vertebrae), anterior-rib (from the seventh cervical vertebra to the fifth thoracic vertebra) and loin-rib (from the sixth thoracic vertebra to the sixth lumbar vertebra). Each joint was weighed. The pelvic limb, loin-rib, anterior rib were classified as valuable cuts. The pelvic limbs were dissected into the muscle, bone, and fat. The percentage of each tissue in the hind leg was calculated. The measurements of the area of the loin "eye" area and the fat thickness over the "eye" muscle were taken on the last rib area.

\section{Chemical analyses}

After dividing the carcass into joints, samples were taken from the middle part of the musculus longissimus dorsi (MLD) muscle to determine the trace elements: $\mathrm{Ca}$, $\mathrm{Mg}, \mathrm{K}, \mathrm{P}, \mathrm{Cu}, \mathrm{Fe}, \mathrm{Se}$, and $\mathrm{Zn}$. Samples of meat and feeds $(0.5 \mathrm{~g})$ and blood plasma $(1 \mathrm{~mL})$ were mineralized in a mixture of $4 \mathrm{~mL} \mathrm{HNO}_{3}$ and $1 \mathrm{~mL} \mathrm{H}_{2} \mathrm{O}_{2}$ in hermetic highpressure vessels by heating in microwave oven. The content of mineral elements was measured by inductively coupled plasma atomic emission spectroscopy (ICP-AES) Optima 5300 DV, Perking Elmer.

\section{Statistical analysis}

The data were analysed using the PROC GLM procedure of SAS (SAS Inst. Inc., Cary, NC, 2010), and test the supplementation effect (C vs $\mathrm{S}$ ) and the housing effect (C vs $\mathrm{G}$ ). Given that the blood parameters were measured on each lamb at the start and end of the experiment we used a repeat measure analysis model with the treatment fixed effect, the random lambs effect nested within treatment, and the interaction between the treatment effect and the time effect. 


\section{RESULTS AND DISCUSSION}

\section{Carcass characteristics}

Average daily gain (AGD) during fattening was similar in high-input (indoor) production groups $\mathrm{C}$ and $\mathrm{S}$ and higher in those groups than in low-input (outdoor) production group $\mathrm{G}$. The lambs in those indoor treatments were offered the same feed (concentrate) better of nutritive value than pasture for grazing lambs. The effect of the fodder quality or changes in weather conditions is known to be a significant source of variation (Mawrogenis and Papachristoforu, 2000). A comparison of half carcasses across the groups has shown no difference between the control group and the one with supplements, while the weight of half carcasses in the grazing group was smaller in comparison with groups $\mathrm{C}$ and $\mathrm{S}(\mathrm{p}<0.001)$. Probably for that reason cuts from the grazing lambs were significantly slighter compared to the ram lambs fattening indoors (Table 2 ). The higher value of the pelvic limb index and the deepness of limbs in groups $\mathrm{C}$ and $\mathrm{S}$ have confirmed their better tightness. Other trials, aimed at characterizing fatness, have confirmed that the content of fat tissue in carcasses obtained from the grazing lambs was lower than that obtained from those fattening indoors (Table 2). The highest fat thickness over the MLD muscle was observed in the group that received $\mathrm{Se}, \mathrm{Zn}$, and vitamin $\mathrm{E}$. No difference in subcutaneous fat thickness was noticed between group $\mathrm{C}$ vs
$\mathrm{S}$, and $\mathrm{C}$ vs $\mathrm{G}$. The kidney weight with perirenal fat in group $\mathrm{G}$ was smaller compared to the control group and to the group with supplementation, by $42 \mathrm{~g}(\mathrm{p}<0.001)$ and $51 \mathrm{~g}$ respectively.

The grazing lambs were slaughtered at the same age as the rams fattening indoors, but the body weight of lambs from group $\mathrm{G}$ at slaughter was lower than in groups $\mathrm{C}$ and $\mathrm{S}$. Consequently, the weight of carcasses was also significantly lower (and their cuts were significantly slighter) in group G. These results suggested that the environmental condition such as exercise, insects, rain and outside temperature were responsible for the observed changes in the growth rate and carcass composition between the concentrate- and grass-fed lambs. Carrasco et al. (2009a) as well as Priolo et al. (2002) also reported that lambs fattening on the pasture were not as well conformed as those maintained indoor. According to many authors, a higher carcass weight positively impacts the weight of carcass sections (Priolo et al., 2002; Peña, et al., 2005; Carrasco et al., 2009b; Rosa et al., 2009; Önenç et al., 2011). The lack of differences in meat content of the pelvic limb between the groups, and, at the same time, the lower fat content $(p<0.001)$ in group $G$, plus the better parameters of pelvic limb tightness in groups $\mathrm{C}$ and $\mathrm{S}$, are evidence of their higher fatness. Grazing lambs had lessdeveloped fat depots due to the limited energy intake. The energy requirements of sheep at pasture were $60 \%$ to $70 \%$ higher than for housed sheep of similar body weight.

Table 2. Effect of housing systems and Se, Zn, and vitamin E supplementation on results of fattening and the carcass quality of lamb

\begin{tabular}{|c|c|c|c|c|c|c|}
\hline \multirow{2}{*}{ Item } & \multicolumn{3}{|c|}{ Group $^{1}$} & \multirow{2}{*}{$\mathrm{SEM}^{2}$} & \multicolumn{2}{|c|}{ p-value ${ }^{3}$} \\
\hline & $\mathrm{C}$ & $\mathrm{S}$ & $\mathrm{G}$ & & C vs S & C vs G \\
\hline Body weight, start (kg) & 14.1 & 14.2 & 14.2 & 0.59 & 0.945 & 0.916 \\
\hline Body weight, final (kg) & 27.5 & 28.4 & 23.7 & 0.71 & 0.463 & 0.002 \\
\hline ADG during fattening $(\mathrm{g} / \mathrm{d})$ & 223 & 237 & 159 & 10.8 & 0.331 & 0.002 \\
\hline Half carcass weight (kg) & 5.9 & 6.19 & 4.33 & 0.22 & 0.308 & 0.000 \\
\hline Pelvic limb deepness $(\mathrm{cm})$ & 20.4 & 20.2 & 18.5 & 0.29 & 0.949 & 0.000 \\
\hline Pelvic limb tightness index (\%) & 145.1 & 145.9 & 126.7 & 1.17 & 0.816 & 0.000 \\
\hline Pelvic limb weight (g) & 1,990 & 2,111 & 1,514 & 328 & 0.208 & 0.000 \\
\hline Loin - rib weight (g) & 851 & 896 & 554 & 8.59 & 0.878 & 0.000 \\
\hline Anterior - rib weight (g) & 439 & 472 & 319 & 9.18 & 0.155 & 0.000 \\
\hline Valuable cuts (g) & 3,280 & 3,478 & 2387 & 48.5 & 0.197 & 0.000 \\
\hline Content of valuable cuts (\%) & 55.7 & 56.2 & 55.2 & 0.13 & 0.345 & 0.133 \\
\hline Thorasic limb wright (g) & 1,089 & 1,139 & 852 & 166 & 0.337 & 0.000 \\
\hline Neck weight (g) & 477 & 479 & 374 & 13.24 & 0.942 & 0.000 \\
\hline Breast weight (g) & 946 & 988 & 657 & 19.6 & 0.427 & 0.000 \\
\hline Loin eye area $\left(\mathrm{cm}^{2}\right)$ & 11.45 & 11.84 & 8.85 & 0.22 & 0.432 & 0.000 \\
\hline Fat over the eye loin (mm) & 1.37 & 1.57 & 1.11 & 0.01 & 0.398 & 0.164 \\
\hline Kidney with perirenal fat (g) & 111 & 120 & 69 & 2.73 & 0.288 & 0.000 \\
\hline Meat in pelvic limb (\%) & 77.2 & 77.1 & 78.5 & 0.30 & 0.848 & 0.079 \\
\hline Fat in pelvic limb $(\%)$ & 9.6 & 9.9 & 6.2 & 0.29 & 0.637 & 0.000 \\
\hline Bones in pelvic limb (\%) & 13.2 & 13.0 & 15.2 & 0.22 & 0.658 & 0.000 \\
\hline
\end{tabular}

\footnotetext{
${ }^{1}$ Group $\mathrm{C}=$ Indoor with no supplement, $\mathrm{n}=19 ; \mathrm{S}=$ Indoor with supplement, $\mathrm{n}=23 ; \mathrm{G}=$ Outdoor with no supplement, $\mathrm{n}=30$.

${ }^{2}$ Standard error of the mean. ${ }^{3}$ Supplementation effect $\mathrm{C}$ vs $\mathrm{S}$ and the housing effect $\mathrm{C}$ vs $\mathrm{G}$.
} 
Movement and changing weather conditions increase the energy expenditure of grazing lambs, thus decreasing fat tissue deposition (Lachica and Aguilera, 2005; Kuźnicka, 2006). Daily energy intake of lambs fattening on the pasture may provide enough energy for bone and muscle tissue development, but not for fat accretion (Carrasco et al., $2009 \mathrm{~b}$ ). Other authors also indicated that carcasses from indoor lambs had better muscular conformation and were fattier than those from grass-fed animals (Peña et al., 2005; Rosa et al., 2009; Carrasco et al., 2009b; Önenç et al., 2011). The maintenance system had a clear effect on the fatness, but the magnitude of that effect varied with the fat depots. Grazing had a lesser effect on internal fat depot (kidney with pelvic fat; $p<0.05)$ than on intermuscular $(p<0.001)$ and on subcutaneous $(\mathrm{p}<0.001)$ fat, in keeping with the findings of other authors (Kuźnicka, 2006; Joy et al., 2008; Carrasco et al., 2009b). The relatively significant differences between the indoor concentrate feeding lambs and grazing lambs suggests that the diet composition had a greater influence on lamb performance and carcass characteristics than did the environmental conditions encountered by the lambs raised on the pasture. Jacques et al. (2011) reported that grass feeding under good pasture management has the potential to provide high-quality carcasses at low cost and should be considered by producers when it is available.

\section{Blood plasma}

Selenium and $\mathrm{Zn}$ concentrations in the blood plasma of lambs are presented in Table 3. A comparison with reference values for Se: 1.01 to $1.95 \mu \mathrm{mol} / \mathrm{L}$ (Hidiroglou et al., 1987; Judson et al., 1988) and for Zn: 12.24 to 18.36 $\mu \mathrm{mol} / \mathrm{L}$ (Cakała, 1981) shows that results obtained in this experiment were within the reference values. The concentrations of Se and $\mathrm{Zn}$ in the blood plasma of ramlambs from the supplemented group were significantly higher than for the control and grazing lambs. The concentrations of Se and $\mathrm{Zn}$ in the blood plasma of grazing lambs after fattening were significantly lower than in control lambs. The contents of Se and $\mathrm{Zn}$ in the fresh grass were lower than in the concentrate given to the other lambs, and this probably influenced on the concentration of Se and $\mathrm{Zn}$ in the blood plasma. The National Research Council (USA) suggested that the Se requirements range for sheep is from 0.1 to $0.2 \mathrm{ppm}$ of dry mater (DM) feed (McDowell, 1992). The Se content in the grass for $G$ group was only $0.09 \mathrm{ppm}$. Current estimates put the maximum tolerable level of Se at $2 \mathrm{mg} / \mathrm{kg} \mathrm{DM}$ for the major livestock species. Davies et al. (2008) reported that the maximum tolerable level of inorganic Se for sheep is much higher than the current estimate of $2 \mathrm{mg} / \mathrm{kg}$ diet. Serum selenium concentrations measured at weeks $12,24,48$, and 60 of the treatment ranged from 110 to $3922 \mu \mathrm{g} / \mathrm{L}$ and increased linearly as dietary Se levels increased from $0.2 \mathrm{mg} / \mathrm{kg} \mathrm{DM}$ to $40 \mathrm{mg} / \mathrm{kg}$ DM. Serum Se concentrations in wethers were affected by dietary Se level, Se source, and the interaction of dietary Se level $\times$ Se source interaction (Davis et al., 2008). Supplementation of Se (up to $400 \mu \mathrm{g} / \mathrm{kg}$ diet) reduced lipid peroxidation in plasma and increased activities of glutathione peroxidase and glutathione reductase, and red blood cell catalase (Rao et al., 2013).

Plasma $\mathrm{Zn}$ concentrations on day 15, 30, 45 and 60 of the experiment were increased from $0.84 \mathrm{mg} / \mathrm{L}$ to 1.42 $\mathrm{mg} / \mathrm{L}$ for all levels of $\mathrm{Zn}$ supplementation and were higher for the treatment group supplemented with 30 and $45 \mathrm{mg}$ $\mathrm{Zn} / \mathrm{kg}$ DM compared with $15 \mathrm{mg} / \mathrm{kg}$ (Jia et al., 2008). Administration of a zinc, cobalt, and selenium soluble glass bolus to growing lambs resulted in significantly increased plasma zinc concentrations, erythrocyte GSHPx activities and serum vitamin $\mathrm{B}_{12}$ compared to control group lambs grazing the same pasture (Kendall et al., 2012). The NRC suggested that $\mathrm{Zn}$ requirement for sheep vary from 20 to 33 $\mathrm{mg} / \mathrm{kg}$ feed DM. For ruminants, overt $\mathrm{Zn}$ toxicosis first appears when levels around 1,000 ppm are incorporated into a natural ingredient diet (Mc Dowell, 1992).

\section{Loin muscle}

The contents of mineral elements in the loin of the lambs are presented in Table 4. The data shows that the concentrations of $\mathrm{P}, \mathrm{Mg}, \mathrm{Fe}$, and $\mathrm{Cu}$ in the meat were comparable among the three groups. Contents of $\mathrm{Ca}$ and $\mathrm{K}$ were highest in the meat from grazing lambs. Grass from areas fertilized with urine and feces are generally higher in calcium and potassium. In the present experiment we did not observe the interaction between the administered levels of $\mathrm{Se}$ and $\mathrm{Zn}$ and the concentrations of $\mathrm{Ca}, \mathrm{K}, \mathrm{P}, \mathrm{Mg}, \mathrm{Fe}$, and $\mathrm{Cu}$ in loin of the lambs. High zinc intakes can inhibit copper and iron absorption. Garg et al. (2008) find the

Table 3. Effect of housing systems and Se, Zn, and vitamin E supplementation on selenium and zinc concentrations $(\mu \mathrm{mol} / \mathrm{L})$ in blood plasma of lambs before and after the end of the experiment

\begin{tabular}{|c|c|c|c|c|c|c|c|c|c|}
\hline \multirow{2}{*}{$\begin{array}{l}\text { Trace } \\
\text { element }\end{array}$} & \multicolumn{3}{|c|}{ Before fattening $^{1}$} & \multicolumn{3}{|c|}{ After fattening } & \multirow{2}{*}{ SEM $^{2}$} & \multicolumn{2}{|c|}{ p-value ${ }^{3}$} \\
\hline & $\mathrm{C}$ & $S$ & G & $\mathrm{C}$ & $S$ & G & & C vs $S$ & C vs G \\
\hline $\mathrm{Se}$ & 1.11 & 1.12 & 1.15 & 1.19 & 1.42 & 1.11 & 0.011 & 0.000 & 0.936 \\
\hline $\mathrm{Zn}$ & 13.05 & 13.21 & 12.98 & 13.29 & 17.66 & 11.95 & 0.188 & 0.000 & 0.335 \\
\hline
\end{tabular}

${ }^{1}$ Group before and after fattening: Group C = Indoor with no supplement; S = Indoor with supplement, $\mathrm{G}=$ Outdoor with no supplement.

${ }^{2}$ Standard error of the mean. ${ }^{3}$ Supplementation effect $\mathrm{C}$ vs $\mathrm{S}$ and the housing effect $\mathrm{C}$ vs $\mathrm{G}$. 
Table 4. Effect of housing systems and Se, Zn, and vitamin E supplementation on contents of mineral elements in the loin of lambs (fresh tissue)

\begin{tabular}{|c|c|c|c|c|c|c|}
\hline \multirow{2}{*}{$\begin{array}{l}\text { Mineral } \\
\text { elements }\end{array}$} & \multicolumn{3}{|c|}{ Group $^{1}$} & \multirow{2}{*}{$\mathrm{SEM}^{2}$} & \multicolumn{2}{|c|}{ p-value ${ }^{3}$} \\
\hline & $\mathrm{C}$ & $S$ & G & & C vs S & $\mathrm{C}$ vs $\mathrm{G}$ \\
\hline $\mathrm{Ca}(\mu \mathrm{g} / \mathrm{g})$ & 101 & 106 & 111 & 1.41 & 0.440 & 0.030 \\
\hline $\mathrm{Mg}(\mu \mathrm{g} / \mathrm{g})$ & 273 & 283 & 263 & 1.72 & 0.062 & 0.072 \\
\hline $\mathrm{K}(\mathrm{mg} / \mathrm{g})$ & 3.92 & 4.02 & 4.08 & 0.02 & 0.280 & 0.013 \\
\hline $\mathrm{P}(\mathrm{mg} / \mathrm{g})$ & 1.93 & 1.86 & 1.77 & 0.03 & 0.695 & 0.057 \\
\hline $\mathrm{Cu}(\mu \mathrm{g} / \mathrm{g})$ & 0.90 & 0.93 & 0.88 & 0.01 & 0.711 & 0.841 \\
\hline $\mathrm{Fe}(\mu \mathrm{g} / \mathrm{g})$ & 23.3 & 24.9 & 22.8 & 0.49 & 0.525 & 0.969 \\
\hline $\mathrm{Se}(\mu \mathrm{g} / \mathrm{g})$ & 0.31 & 0.46 & 0.26 & 0.004 & 0.000 & 0.000 \\
\hline $\mathrm{Zn}(\mu \mathrm{g} / \mathrm{g})$ & 23.4 & 32.9 & 21.9 & 0.37 & 0.000 & 0.289 \\
\hline
\end{tabular}

${ }^{1}$ Group C = Indoor with no supplement; S = Indoor with supplement; G = Outdoor with no supplement.

${ }^{2}$ Standard error of the mean. ${ }^{3}$ Supplementation effect $\mathrm{C}$ vs $\mathrm{S}$ and the housing effect $\mathrm{C}$ vs $\mathrm{G}$.

effect of supplementation of $20 \mathrm{mg} \mathrm{Zn} / \mathrm{kg}$ DM only on serum Fe contents. However, there was no effect of either $\mathrm{ZnSO}_{4}$ or $\mathrm{Zn}$-meth supplementation on serum $\mathrm{Cu}, \mathrm{Ca}, \mathrm{P}$, and Mn concentration (Garg et al., 2008). The Se and $\mathrm{Zn}$ concentrations in the muscle of the supplemented group were significantly higher than those in the unsupplemented control and grazing groups. The contents of Se and $\mathrm{Zn}$ in the concentrate $(0.16$ and $27.2 \mathrm{ppm}$, respectively) were higher than in grass $(0.09$ and $15.1 \mathrm{ppm})$ and this probably influenced the concentration of Se and $\mathrm{Zn}$ in the loin of the lambs. Quin et al. (2007) reported that the diet supplement with sodium selenite from $0.06 \mathrm{mg} / \mathrm{kg} \mathrm{DM}$ (basal diet) to $0.15 \mathrm{mg} / \mathrm{kg} \mathrm{DM}$ significantly increased Se concentration in muscle from $0.087 \mathrm{mg} / \mathrm{kg}$ to $0.156 \mathrm{mg} / \mathrm{kg}$. The Se concentration of the muscle in the group supplemented with sodium selenite was lower than those in the group supplemented with selenized yeast and Se-ennriched probiotics (Quin et al., 2007). Tian et al. (2006) reported that both dietary Se source (inorganic and organic) and Se level influenced the Se concentration of various pig tissues and serum. Vignola et al. (2009) found that lambs supplemented with $0.30 \mathrm{mg} / \mathrm{kg}$ Na selenite or Se-yeast had a significant increase in the Se concentration in muscle from 0.35 to 0.43 and $0.66 \mu \mathrm{g} / \mathrm{g}$ dray weight. Selenium concentrations in the loin muscle, which is often consuming by mankind ranged from 0.71 to $26.87 \mathrm{mg} / \mathrm{kg}$ and tended to increase linearly as dietary Se was increased (Davis et al., 2008).

Shi et al. (2011) reported that Se concentration in muscle tissue was notably higher in inorganic Sesupplemented growing male goats compared to an unsupplemented goats $(0.5036 \mu \mathrm{g} / \mathrm{g}$ vs $0.2049 \mu \mathrm{g} / \mathrm{g})$. A basal diet supplemented with $\mathrm{Se}$-enriched yeast to increase dietary Se concentration to $0.5 \mathrm{mg} / \mathrm{kg}$ significantly increased Se concentration in MLD of veal from 0.21 to $0.43 \mathrm{mg} / \mathrm{kg}$ (Skrivanova et al., 2007). In this experiment the basal diet supplemented with inorganic Se significantly increased Se concentration in MLD of lambs from 0.31 to $0.46 \mathrm{mg} / \mathrm{kg}$ fresh tissue.

Selenium is implicated in antioxidant functions, and selenocysteine complex is essential in the active centres of Se-enzymes that carry out redox reactions, glutathione peroxidase (GPx), thyroid hormone deiodinase families and thioredoxinreductase (Tapiero et al., 2003; Hefnawy and Tórtora-Pérez, 2010). Vitamin E is primarily active as an antioxidant protecting PUFA in vivo and post-mortem in animal tissues and muscle nutrients from free-radical attack (Morrissey et al., 1994). Two consecutive injections of Se (before mating and lambing) significantly increased incidence of oestrus, fertility, lamb body weight at day 28 and daily weight gain for 28 days in 3-year-old ewes (Gabryszuk and Klewiec, 2002). Zinc is associated with enzymes, both as part of the molecule and as an activator. In its structural role, $\mathrm{Zn}$ usually stabilizes the structures of RNA, DNA, and ribosomes (McDowell, 1992). Zn superoxide dismutase (ZnSOD) is a dietary factor which contributes to the antioxidant defense system (Morrissey et al., 1998).

The recommended daily allowance (RDA) for zinc ranges from 8 to $16 \mathrm{mg} / \mathrm{d}$ (10 $\mathrm{mg}$ mean) for adults in different countries (Schlegel-Zawadzka, 2011). The RDA for Se in humans is from $30 \mu \mathrm{g} / \mathrm{d}$ to $75 \mu \mathrm{g} / \mathrm{d}$ (55 $\mu \mathrm{g}$ mean) independent of the country (Fairweather-Tait et al., 2011). In the present study, a 100-g portion of the skeletal muscle from lambs fed inorganic Se sources would provide approximately $84 \%$ of the RDA for Se and approximately $33 \%$ of the RDA for $\mathrm{Zn}$. It should be remembered that both deficient and excessive levels of selenium in the diet are not beneficial to human health. There exist studies have demonstrated potential protective (for humans) effects of plasma/serum selenium levels between $120-160 \mathrm{ng} / \mathrm{mL}$ and a reduced risk of some types of cancer compared to the low plasma selenium levels, namely $<120 \mathrm{ng} / \mathrm{mL}$. Above 160 $\mathrm{ng} / \mathrm{mL}$ the protective effect against cancer is likely to diminish and probably an increased risk for some types of 
cancer will be noticed (Fairweather-Tait et al., 2011). As the daily intake of $\mathrm{Se}$ and $\mathrm{Zn}$ by humans is declining in some parts of the world, increasing the Se and $\mathrm{Zn}$ content in food for human consumption by manipulating the source and level of Se and $\mathrm{Zn}$ supplementation to livestock is now of interest to food scientists. Our findings indicate that Se and $\mathrm{Zn}$ contents in muscle can be influenced by $\mathrm{Se}$ and $\mathrm{Zn}$ supplementation to animal food. Meat is a good source of essential trace elements such as $\mathrm{Se}, \mathrm{Zn}, \mathrm{Cu}, \mathrm{Fe}$ for humans and a better one than plant and milk foods.

\section{CONCLUSIONS}

The carcasses of grazing lambs contained less fat compared to the control and supplemented groups. The maintenance of ram lambs on the pasture during the fattening period may contribute to the yield of lean meat, in accordance with consumers' demands. The housing system can have an influence on the mineral elements concentration in the muscle, especially on the areas deficient in mineral elements. In general, inorganic Se and Zn may also be absorbed and assimilated into the body's skeletal muscles and is cheaper than organic selenium and zinc. This is good news for developing countries. Additionally, beef industry may derive benefit from this research as a model of feeding beef cattle to achieve the selenium and zinc status for the purpose of niche marketing.

\section{ACKNOWLEDGEMENT}

Research was realized within the project "BIOFOOD innovative, functional products of animal origin no. POIG.01.01.02-014-090/09 co-financed by the European Union from the European Regional Development Fund within the Innovative Economy Operational Programme 2007-2013.

\section{REFERENCES}

Carrasco, S., G. Ripoll, A. Sanz, J. Alvarez-Rodrigez, B. Panea, R. Revilla, and M. Joy. 2009a. Effect of feeding system on growth and carcass characteristics of Churra Tensina light lambs. Livest. Sci. 121:56-63.

Carrasco, S., G. Ripoll, B. Panea, J. Álvarez-Rodríguez, and M. Joy. 2009b. Carcass tissue composition in light lambs: Influence of feeding system and prediction equations. Livest. Sci. 126: 112-121.

Cąkała, S. 1981. Diseases of Sheep (in polish). PWRiL, Warsaw, Poland.

Davis, P. A., L. R. McDowell, N. S. Wilkinson, C. D. Buergelt, R. Van Alstyne, R. N. Weldon, T. T. Marshall, and E. Y. MatsudaFugisaki. 2008. Comparative effects of various dietary levels of Se as sodium selenite or Se yeast on blood, wool, and tissue Se concentrations of wether sheep. Small Rumin. Res. 74: 149158
Fairweather-Tait, S. J., Y. Bao, M. R. Broadley, R. Collings, D. Ford, J. E. Hesketh, and R. Hurst. 2011. Selenium in human health and disease. Antioxid. Redox. Signal. 14:1337-1383.

Gabryszuk, M., M. Czauderna, A. Baranowski, N. Strzałkowska, A. Jóźwik, and J. Krzyżewski. 2007. The effect of diet supplementation with $\mathrm{Se}, \mathrm{Zn}$ and vitamin $\mathrm{E}$ on cholesterol, CLA and fatty acid contents of meat and liver of lambs. Anim. Sci. Pap. Rep. 25:25-33.

Gabryszuk, M. and J. Klewiec. 2002. Effect of injecting 2- and 3year-old ewes with selenium and selenium-vitamin $\mathrm{E}$ on reproduction and rearing of lambs. Small Rumin. Res. 43:127132.

Garg, A. K., V. Mudgal, and R. S. Dass. 2008. Effect of organic zinc supplementation on growth, nutrient utilization and mineral profile in lambs. Anim. Feed Sci. Technol. 144: 82-96.

Hefnawy, A. E. G. and J. L. Tórtora-Pérez. 2010. The importance of selenium and the effects of its deficiency in animal health. Small Rumin. Res. 89:185-192.

Hidiroglou, M., A. J. Mcallister, and C. J. Williams. 1987. Prepartum supplementation of selenium and vitamin E to dairy cows: Assessment of selenium status and reproductive performance. J. Dairy Sci. 70:1281-1288.

Jacques, J., R. Berthiaume, and D. Cing-Mars. 2011. Growth performance and carcass characteristics of Dorset lambs fed different concentrates: Forage ratios or fresh grass. Small Rumin. Res. 95:113-119.

Judson, G. J., T. H. Brown, B. R. Kempe, and R .K. Turnbull. 1988. Trace element and vitamin $B_{12}$ status of sheep given an oral dose of one, two or four soluble glass pellets containing copper, selenium and cobalt. Aust. J. Exp. Agric. 28:299-305.

Jia, W., Z. Jia, W. Zhang, R. Wang, S. Zhang, and X. Zhu. 2008. Effects of dietary zinc on performance, nutrient digestibility and plasma zinc status in Cashmere goats. Small Rumin. Res. 80:68-72.

Joy, M., G. Ripoll, and R. Delfa. 2008. Effects of feeding system on carcass and non carcass composition of Churra Tensina light lambs. Small Rumin. Res. 78:123-133.

Kendall, N. R., A. M. Mackenzie, and S. B. Telfer. 2012. The trace element and humoral immune response of lambs administered a zinc, cobalt and selenium soluble glass bolus. Livest. Sci. 148:81-86.

Krupiński, J. 2009. Meat Performance Evaluation According to the Methodology Using in European Union (in polish). National Research Institute of Animal Production, Kraków, Poland.

Kuźnicka, E. 2006. The effect of forced walking on slaughter value and meat quality of lambs: Linking up the meat chain: ensuring quality and safety for the consumer. Conference, Krakow, Poland, Anim. Sci. Vol. 1(Suppl.):162-164.

Lachica, M. and J. Aguilera. 2005. Energy expenditure of walk in grassland for small ruminants. Small Rumin. Res. 59:105-121.

Mavrogenis, A. P. and C. Papachristoforou. 2000. Genetic and phenotypic relationship between milk production and body weight in Chios sheep and Damascous goats. Livest. Prod. Sci. 67:81-87.

McDowell, L. R. 1992. Minerals in Animal and Human Nutrition. Academic Press, Inc., San Diego, CA, USA.

Morrissey, P. A., P. B. Quinn, and P. J. A. Sheehy. 1994. Newer aspects of micronutrients in chronic disease: Vitamin E. Proc. Nutr. Soc. 53:571-582. 
Önenç, S. S., M. Özdoğan, F. E. Ataç, and T. Taşkin. 2012. Fattening performance and carcass traits of Chios male lambs fed under traditional and intensive feeding conditions. Trop. Anim. Health Prod. 44:1057-1062.

Peña, F., T. Cano, V. Domenech, Ma.J. Alcalde, J. Martos, A. Garcia-Martinez, M. Herdera, and E. Roberto. 2005. Influence of sex, slaughter weight and carcass weight on "non-carcass and carcass" quality in Segurena lambs. Small Rumin. Res. 60: 247-254.

Priolo, A., D. Micol, J. Agabriel, S. Prache, and E. Dransfield. 2002. Effect of grass or concentrate feeding systems on lamb carcass and meat quality. Meat Sci. 62:179-185.

Quin, S., J. Gao, and K. Huang. 2007. Effects of different selenium sources on tissue selenium concentrations, blood GSH-Px activities and plasma interleukin levels in finishing lambs. Biol. Trace Elem. Res. 116:91-102.

Rao, S. V. R., B. Prakash, M. V. L. N. Raju, A. K. Panda, S. Poonam, and O. K. Murthy. 2013. Effect of supplementing organic selenium on performance, carcass traits, oxidative parameters and immune responses in commercial broiler chickens. Asian Australas. J. Anim. Sci. 26:247-252.

Rosa, H. J. D., O. A. Rego, L. R. Evangelho, C. C. G. Silava, A. E. S. Borba, and R. J. B. Bessa. 2009. Growth performance and carcass characteristic of Holstein bulls reared exclusively on grass or finished with ground maize. 60th Annual Meeting of European Federation of Animal Science, EAAP 2009. Session S05. 2009 August 24; Barcelona, Spain. p. 40.
Schlegel-Zawadzka, M. 2011. Role of zinc in health. 11th European Nutrition Conference. 2011 October 26-29; Madrid, Spain. Programme, 18.

Shi, L., W. Xun, W. Yue, C. Zhang, Y. Ren, L. Shi, Q. Wang, R. Yang, and F. Lei. 2011. Effect of sodium selenite, Se-yeast and ano-elemental selenium on growth performance, Se concentration and antioxidant status in growing male goats. Small Rumin. Res. 96:49-52.

Skrivanova, S., M. Marounek, S. De Smet, and K., Raes. 2007. Influence of dietary selenium and vitamin $\mathrm{E}$ on quality of veal. Meat Sci. 76:495-500.

SAS/STAT. 2010. User's Guide, version 9.2, SAS Inst. Inc., Cary, NC, USA.

Tapiero, H., D. M. Townsend, and K. D. Tew. 2003. The antioxidant role of selenium and selenocompounds. Biomed. Pharmacother. 57:134-144.

Tian, J. Z., M. S. Yun, C. S. Kong, L. G. Piao, H. F. Long, J. H. Lee, J. S. Lim, C. H. Kim, Y. Y. Kim, and In K. Han. 2006. Effect of different products and levels of selenium on growth, nutrient digestibility and selenium retention of drowingfinishing pigs. Asian Australas. J. Anim. Sci. 19:61-66.

Vignola, G., L. Lambertini, G. Mazzone, M. Giammarco, M. Tassinari, G. Martelli, and G. Bertin. 2009. Effects of selenium source and level of supplemention on the performance and meat quality of lambs. Meat Sci. 81:678-685. 